\title{
PROBLEMS OF MOTHERS RAISING A CHILD WITH INTELLECTUAL DISABILITY
}

\section{PROBLEMY MATEK WYCHOWUJĄCYCH DZIECKO Z NIEPEŁNOSPRAWNOŚCIĄ INTELEKTUALNĄ}

\author{
Dorota Tomczyszyn ${ }^{1(\mathrm{~A}, \mathrm{~B}, \mathrm{C}, \mathrm{D}, \mathrm{E}, \mathrm{F}, \mathrm{G})}$
}

\author{
${ }^{1}$ Pope John Paul II State School of Higher Education in Biała Podlaska, Poland
}

Authors' contribution Wkład autorów:

A. Study design/planning zaplanowanie badań B. Data collection/entry zebranie danych

C. Data analysis/statistics dane - analiza i statystyki D. Data interpretation interpretacja danych E. Preparation of manuscript przygotowanie artykułu F. Literature analysis/search wyszukiwanie i analiza literatury G. Funds collection zebranie funduszy
Tables: 0

Figures: 0

References: 26

Submitted: 2019 Sep 20

Accepted: 2019 Oct 25

\section{Summary}

Background. Children with intellectual disability need special help from their parents, proportional to the type and degree of their disability. They require individual treatment, and their development depends not only on their health status but also on environmental conditions, measures and actions taken by supporting institutions, and social attitudes. Most often, mothers engage in a child care by giving up their own professional career, interests and social interactions. While raising a child, they face many adversities, and they are often helpless to overcome them. The aim of this work is to analyze the most important problems of mothers raising a child with intellectual disability.

Material and methods. The research was of a qualitative nature. Case studies were used based on the method of unstructured interview and structured interview. Each interview lasted about 2 hours. The participants of interviews were four mothers bringing up children with intellectual disabilities.

Results. The mothers who participated in the research pointed out negative social attitudes in the environment. They reported ambiguous situations in institutions supporting the family and the problems in the health care of their disabled children. Women's dreams focused around a child, his or her health and future.

Conclusions. There is a need to formulate procedures for dealing with an intellectually disabled patient in hospital wards, to attempt to regulate the institutional support for daily activities of adult, dependent people with intellectual disabilities.

Keywords: mother of a child with disability, intellectual disability, qualitative research

\section{Streszczenie}

Wprowadzenie. Dziecko z niepełnosprawnością intelektualną potrzebuje od rodziców specjalnej pomocy, proporcjonalnej do rodzaju i stopnia niepełnosprawności. Wymaga ono indywidualnego traktowania, a jego rozwój zależy od stanu zdrowia, ale także od warunków środowiskowych, działania instytucji wspierających, postaw społecznych. Najczęściej w opiekę nad dzieckiem angażują się matki rezygnując z własnej, zawodowej kariery, zainteresowań, kontaktów społecznych. W wychowaniu dziecka napotykają na wiele przeciwności, wobec których często są bezradne. Celem pracy będzie analiza najważniejszych problemów matek wychowujących dziecko z niepełnosprawnością intelektualną.

Materiał i metody. Badania miały charakter jakościowy. Wykorzystano analizę indywidualnych przypadków na podstawie metody wywiadu swobodnego oraz wywiadu skategoryzowanego. Każdy wywiad trwał około 2 godzin. W wywiadach uczestniczyły 4 matki wychowujące dzieci z niepełnosprawnością intelektualną.

Wyniki. Badane matki wskazywały na negatywne postawy społeczne otoczenia. Opowiadały o niejednoznacznych sytuacjach w instytucjach wspierających rodzinę i problemach w opiece zdrowotnej ich niepełnosprawnych dzieci. Marzenia kobiet koncentrowały się wokół dziecka, jego zdrowia i jego przyszłości.

Wnioski. Istnieje potrzeba wypracowania procedur postępowania w przypadku niepełnosprawnego intelektualnie pacjenta $\mathrm{w}$ oddziałach szpitalnych, podjęcia próby uregulowania instytucjonalnego wsparcia aktywności codziennej dorosłych, niesamodzielnych osób z niepełnosprawnością intelektualną.

Słowa kluczowe: matka dziecka z niepełnosprawnością, niepełnosprawność intelektualna, badania jakościowe 


\section{Introduction}

As a result of the development of women's cultural capital in the last decade in Poland, there have been significant changes in the role of women. It can be said that the differences between men and women are beginning to blur when it comes to expectations related to work, or to the roles played in the public sphere. However, the differences in performing cultural roles are still big, which is the result of the traditional perception of women and men [1]. Budrowska points out the stereotypical perception of mothers in the Polish society, where a child is seen as most important, a woman as called to motherhood, and where the ideal mother must be always patient, understanding, and give her child continuous and unconditional love [2]. From these social expectations the conclusion can be drawn that it is the mother who is most burdened with responsibility for the child, and the discourse on family problems should focus mainly on the experience of mothers [3]. In this context, the article is based on the statements of mothers raising a child with intellectual disability.

Qualitative research on mothers raising a child with intellectual disability has been carried out by Lindyberg. Describing motherhood with a disabled child, the author negates the claim about handicapped motherhood, but emphasizes the fact of loneliness of women and the emotional side of this kind of motherhood, often marked by suffering. In the presented biographies, based on the experience of mothers, the topic of giving a birth to a disabled child also appears. According to the author, a child may be expected, but it may also appear in the life of a mother-to-be as a surprise. In both cases her current life changes. In the first case, it is the woman who decides to enlarge the family at the time most convenient to her. Gradually, she anticipates changes that are going to take place and she prepares for them. In the second case, a woman is often unprepared for changes in her life [4].

According to Dąbrowska, the mere fact of being told that a child will be born with a deficit poses a crisis and causes shock. Later, another stressor appears - discrepancy between the development of other children and the development of one's own child, as well as discrepancy between one's own expectations and the existing situation [5].

Maciarz states that "difficult motherhood is expressed by negative experiences and emotional states of the mother, her moral dilemmas and disorders of performing a maternal role" [6]. Dąbrowska points to the phenomenon of burnout of mothers raising a child with a disability. This syndrome is characterized by a state of mental and physical exhaustion, which is accompanied by various symptoms. It is a slow process, that takes an individual course for each mother, and it is the result of adding up and accumulating of problems, failures, and emotional tensions. "Burn-out" affects all aspects of a burned-out person's life, and also affects all people who enter into various relationships with her, especially her family [5].

Goldenberg and Goldenberg indicate that, despite these difficulties, family members raising a child with developmental disorders, when faced with the adversities of everyday functioning, often are able to activate their strength, immunity and internal potential, as well as various mechanisms, to deal with this situation [7].

Intellectual disability is associated with permanent changes in the central nervous system and with various types of disorders in its functioning. Obuchowska pointed out that children with intellectual disabilities and other disabled children belong to the category of children with lesser opportunities. She defines these children as "those who, compared to most of their peers, are from the beginning of their development, or from its early period, threatened by limited possibilities of meeting their basic needs and social expectations..." [8].

Providing an intellectually disabled child with optimal conditions for his or her development in the family requires a lot of knowledge, skills and competences of mothers who most often give up their professional work to take care of the child. Families bringing up children with intellectual deficits should be supported in the social and economic sphere, because when caring for a disabled child, apart from the needs typical for all children, there are additionally very specific needs that should also be met.

The aim of this article will be to diagnose the most important problems in a retrospective view of mothers raising a child with intellectual disability.

\section{Material and methods}

The social and institutional problems of families with children with disabilities, amply described as part of the quantitative research, have become the inspiration for the author of this article to undertake qualitative research among mothers caring for a disabled child.

Individual case analyses were used, based on the method of unstructured interviews, which were recorded on a voice recorder, and structured interviews aimed to obtain data on the social, material and demographic situation of the women surveyed. The mothers were asked about the difficulties in their daily existence, about 
their dreams, and how they envision the future of their children with disabilities. When talking with mothers, the author of the article tried to maintain the attitude of a passive listener, sometimes asking about the details of the described situations.

The research was conducted at the turn of the years 2017 and 2018. Each conversation lasted from one to two hours. Four mothers participated in the interviews, two of them were raising children alone, and two in full families. The women did not work, they took care of children with disabilities. One of the women had twins with disabilities, the other women had one child with a disability. The children had moderate or severe intellectual disability.

\section{Detailed social characteristics and material situation of the interviewed mothers}

The first of the mothers, Wioleta, is a young, 33 years old woman, with secondary education. She does not work, she takes care of her son. She raises two sons alone. She is divorced, conflicted with the father of the boys; her husband blamed her for giving birth to a disabled child, he does not maintain any contact with his sons. After divorce, Wioleta returned to her parents. For 3 years now, she has been living with her sons, parents and two siblings in a family home. After being left by the father, the woman was deprived of financial resources, and although she asked for institutional help, she received help from a social assistance center after 3 months. She claims that if it was not for her immediate family, especially her parents, she does not know where she would have lived and how she would have feed her children. Currently, she estimates her financial situation as relatively good.

Her son, Michał, is currently 11 years old, and he is diagnosed with moderate intellectual disability and autism. He is a pretty, nice boy, independent of his everyday activities, he has no difficulty with verbal communication. He has artistic and musical talent, he has participated in art competitions many times and has won awards at the voivodship level. His another passion is dancing. However, he has no friends among non-disabled children. His mother is engaged in the care of her child. She tries to help Michał to develop his interests. She takes care that he spends his free time actively. She is convinced that sport, riding bicycle, and other physical activities are helpful in the boy's state of agitation. It is pleasant for her to talk about Michał, she is proud of him; she says that the boy has a good heart, and is extraordinarily sensitive: (quote) "when I bought him a new sweatshirt, he cried and did not want to wear it to school because other children did not have such a sweatshirt".

Another woman, Krystyna, is 60 years old and she has basic education. She does not work professionally, but takes care of his son with a disability. She is an extremely open person, very peaceful and self-confident. Her attitude results from the fact that her family - mostly her husband and children - are a great support for her. I quote: "When I gave birth to my boy, the hospital ward was closed (due to some bacteria). I was alone. On the other day I was told about Down syndrome, and that these children were short lived. It was a hard experience for me. It was not until two days later that I called my daughter and told her that she had a brother with Down syndrome and that he needed to be loved. She replied that we already loved him. She took care of him, helped me with bathing, rehabilitation, even though she was only 14 years old. Maybe that was the reason why later she graduated from the nursing school and wrote a dissertation paper about disability. My husband was so proud to carry his son from the hospital to the car that it made me feel happy. The older son was in France at that time but it was him who chose the name for his younger brother".

Krystyna has five children, four of them are already adult and independent - they started their own families and live outside the family home. The fourth, youngest son, Konrad, was born when his mother was 40 years old. He is 21 years old now, he is diagnosed with severe intellectual disability and Down syndrome. He is a relatively independent boy. Konrad and his parents live in a block of flats, the mother estimates their financial situation as relatively good.

Parents, especially Konrad's mother, support their son's musical interests. Konrad learns to play various musical instruments. His passion is also being developed in the special school by a music teacher. In addition, a teacher comes to the boy's home to teach him how to play the guitar. The boy has no friends among nondisabled peers.

The boy's mother is a socially active person. She often supported other young mothers who had children with Down syndrome. They were women living in her town. She invited them to her home or offered help in the form of correspondence. These mothers came to her after the publication of her experiences in the magazine "Bardziej Kochani", a quarterly published since 1997 by the Association of Families and Caregivers of People with Down Syndrome (Stowarzyszenie Rodzin i Opiekunów Osób z Zespołem Downa). The woman is the Chairwoman of the Parents' Council at the Complex of Special Education Schools (Zespół Szkół Specjalnych) in Biała Podlaska. 
The third mother, Beata, is 44 years old; she has a secondary education, she does not work professionally, and raises her daughter Iza, whom she drives by car to a special school 5 kilometers away from home every day. She is supported by her husband Rafał. They and their daughter live in the house. She describes their financial situation as relatively good. Their older son has already became independent, he studies, works and lives in Warsaw. Iza is not independent. She is already 22 years old, has significant intellectual disability, and she uses a wheelchair. The girl has no friends among non-disabled peers. Beata is the head of the Association operating at the Complex of Special Education Schools (Zespół Szkół Specjalnych) in Biała Podlaska. In the conversation, the mother's anxiety about the future of her child could be sensed. A woman worries about what will happen in two years when her daughter graduates from school. She would not like her daughter to stay at home, but she may lose "the fight" (quote) for a place for her at WTZ (Warsztaty Terapii Zajęciowej = Occupational Therapy Workshops) due to limited independence of the child.

The fourth woman, Anna, is 40 years old, she raises twin girls with significant disabilities (Kinga and Katarzyna). The girls are 19 years old. The woman also has a younger daughter, Magda, who often gives her mother support and assistance. The mother does not maintain contact with the father of the girls, and the relationship with her in-laws is cold and distant. Although Anna has a university degree, she does not work professionally. All her activity has been directed to the performance of the role of mother. The woman is raising three children and lives in a block of flats. She estimates her financial situation as relatively good. The girls are quite independent. The mother points to the difficulties in providing healthcare, obtaining information about disability and the rights of people with disabilities.

\section{Results}

\section{Social perception of people with disabilities - "On the bus"}

The role of social attitudes towards children with disabilities perceived by their mothers is of particular importance. It is one of the factors having impact on their self-assessment as a mother. Particularly severe negative attitudes of the environment are felt by children with disabilities, who perceive curious glances, or insistent looking at them as an assessment of their person as someone worthless, strange, or different.

The statements of the surveyed women, describing some situations in public transport may serve as examples. Most often, mothers described situations that took place during their way to school and back home.

Anna says: "(disabled children) are perceived differently on the bus when traveling. It is easier with a child (with a visible disability). People say: please, sit down. But in the case of my girls, for example, a typical disability cannot be instantly noticed, and moreover, they are over 20 years old. They have problems with body balance, with differences in levels, with steps. For me, it is very difficult to keep them by the hand on the bus when I am aware that one of them may suddenly "wobble" to the right and the other "to the left". You know, the bus is crowded, so it is easier for me to seat them. But then, it is seen as: "wow! young, nicely dressed girls etc. ... and they are sitting". And then it becomes awkward. My friend from the special school has a child with cerebral palsy with all four limbs affected, in a wheelchair - this disability can be instantly noticed. Then people find it easier to "show pity" and to help. For her, it is easier on the bus. But I have to always explain why my child is sitting".

Therefore, there is a principle that the lack of visible disability causes more restrictive social reactions. According to Larkowa, a positive or negative attitude towards a person with disabilities is affected not so much by the type of impairment as by its visibility and by the severity of the body's function disorder, as well as by the personality traits of the disabled individual and the level of being acquainted with him or her (negative attitudes are more common towards disabled people who are strangers to us) [9].

The next statement emphasizes the attitude of insistent looking, and also describes the reaction of a disabled boy's mother who has got irritated by this.

Krystyna: "I help mothers in a special school, especially mothers of children in early intervention. You need to be open, many mothers withdraw after giving birth to their baby. They do not go out with the child, they are ashamed of their behavior, for example in the church, they constantly admonish their children - to satisfy others. My son likes singing, I used to silence him on the bus, for example because he tried to sing the Polish national anthem loudly "Poland Is Not Yet Lost" (Jeszcze Polska nie zginęła) ..." - I insisted that he cannot do it on the bus. Then he stopped singing but got up and began to say loudly: "Our Father in heaven...". Now I do not admonish him any more if his behavior does not harm anyone. Young people treat children with disabilities better, older people - worse. Once, one lady on the bus was staring at my son insistently, she would not stop, so I asked her: Have you already seen enough? Then she turned her head to the window. Maybe she understood...". 
There is always a dilemma: whether to stand on the side of the child or to avoid social confrontation. This mother was able to point out the behavior of social ignorance and tactlessness, and to stand in opposition to thoughtless social attitudes. Another mother experienced a similar attitude of a public transport passenger: "My son has some balance disturbance. When I seated him on the bus, an elderly person criticized me quite blatantly. But I do not have to explain myself to everyone".

Mothers experience unpleasant emotions when their children are being stared at persistently. It is difficult for them to accept the curiosity of the surroundings, and constant comparing their child with others. They either try to intervene or they withdraw. Avoiding interaction can cause frustration and humiliation due to the child being different.

\section{Cooperation with institutions in the environment}

Other problematic situations reported by mothers raising children with disabilities are related to the functioning of institutions aimed for people with disabilities and health care institutions. From the statements of women emerges the image of often incompetent clerks of these institutions, sometimes characterized by a sense of "superiority" towards the claimants. The helplessness of women against unfavorable regulations or a bureaucratic healthcare system can also be noticed.

Wioleta: "I had constricted contact with PFRON (Państwowy Fundusz Rehabilitacji Osób Niepełnosprawnych = State Fund for the Rehabilitation of the Disabled), and with MOPS (Miejski Ośrodek Pomocy Społecznej = City Social Welfare Centre). These institutions are to help us, but they do not help much. When we enter the institution, they look down on us because we take money for nothing. If we want something to be subsidized, it is difficult because we have a large income. Is PLN 1,406 a large income indeed? For this money we have to support our children, pay for rehabilitation, clothing, special food. The officials are not friendly in contact, they reject us in advance, they hide behind regulations that do not even exist. To obtain help we have to trample the path, and then walk it for two or three years. It was like that in my case. They hide behind the regulations, they think that we do not know them, that we get lost. But we do know them. It is similar at PFRON, they condescend to grant rehabilitation camps, diapers, etc., you need to fill in lots of documents. We, mothers of disabled children, are with our children 24/7, and the government pays us PLN 1,406. For this money, we have to support the children, (buy) food, pampers, rehabilitation camps. If the parent needs to go to the camp with a child, they must paid for it. The grand-aid depends on income, but you always need to pay part of the costs, only the child has a camp for free. But the child will not go alone, children are often not independent enough to go on a camp without a parent. The child cannot do it alone. It hurts me badly how the state treats mothers of disabled children. I have a son with some autism traits, with moderate disability. At first contact it looks like everything is fine, but when you sit and talk to him, all the defects become apparent".

Beata: "There was such a case: the child stood before a medical committee to be granted a disability pension, the certifying doctor told her to put a signature. I said to the mother: Anna, do not allow this under any circumstances, because your daughter is legally incapacitated and cannot sign documents. I finally got into the car, took that mother, went to the certifying doctor with her and explained that he has no right to force the child to sign".

A family fulfills its tasks towards a disabled child in a proper way if it receives appropriate assistance, especially in situations resulting from everyday problems [10]. In these cases, the system did not always work properly. A bureaucratic system, unfriendly attitude of officials, and in some cases lack of knowledge - these are the situations that the women had to face. However, attention should be paid to the self-help provided to one another by mothers raising children with disabilities.

Mothers proved themselves to be resourceful and active in dealing with their issues and problems. This conclusion is confirmed by subsequent mothers' statements regarding medical problems.

Krystyna: "Konrad had his teeth removed and dental plates inserted, but they were faulty and he was choking. I went to the NFZ (Narodowy Fundusz Zdrowia = National Health Fund) and asked for new plates, but the clerk said that the child is entitled to them only every 5 years. I was insisting, explaining that I was afraid he might suffocate. I live in the same city district where the school is located. When I see an ambulance passing, I am waiting for a call with anxiety - call from the school, that my child has suffocated. I cannot wait for 5 years.

The clerk still insisted that I should wait 5 years. I asked: will I get help only when the tragedy already happened? I was insistent and the clerk said that perhaps I could try my luck at the clinic in Lublin - but she did not know if that would work. Anyway, she gave me their address. I wrote an e-mail and described my situation. After two days I received the answer. They told me that I should go to Lublin, to the clinic. I went there with Konrad. The symposium gathered, they examined Konrad and immediately set a date for the procedure. We 
received help within one week. The chief consultant said that the plates may be replaced as often as the situation requires it, even several times a year, because my son is still growing. In Biała Podlaska they claimed something quite opposite. If I had not insisted, I would not get help for my son. You need to inquire into everything, never give up; do not tell me today that this is typical. You have to ask around. I always tell other mothers: ask around".

Wioleta: "Doctors... we do not have proper specialists, we have to demand them ourselves, we need to look for doctors, the health fund does not have the doctors we need".

Beata: "This hospital is supposedly so nice, so big, but I do not know... These doctors, the whole institution... Don't they get any training how to approach a person with disabilities, a disabled child? Recently there was such a case: one of the mothers at school told that her daughter had some gynecological problems. Mother takes her to the hospital ward, asks what she should do and they... they don't know. They say that this is the first case of this kind, they don't know whether to place the girl in the hospital ward, they simply do not know. They advise to go to the disabled people coordinator, but the coordinator-doctor "blinks at them", and says; the head of the ward is not present today, and this is the first case of this kind. Such a trailing, up-and-down, up-and-down; if the mother is resourceful, she will manage. But there are a lot of parents who are backward, they do not cope. This is even more afflictive when a child is closed at home, for example if he or she has individual homeschooling. A child's mother cannot leave the home, she looks after the child, cannot go out to people. Even if she was previously a normal woman, now she can be so confused, so limited. And this is so that the day passes, and another day, it does not "go forward", just another day, and one more day... An institution is needed, a place where she could turn for help, where things would be arranged for a mother, where she would get some advice. Today, parents share information among themselves. This is the main source of information for them: from mother to mother. But mothers of children with individual homeschooling do not have such a chance".

Krystyna: "When we have to wait long in the medical center, my son gets impatient, but nobody wants to let us be served first. If I ask for this, I am forced to listen to such things that I do not even want to repeat".

Of course, it should be noted that these are the statements made only by one of the parties, i.e. by the mothers. A picture of the entire situation should be complemented by the opinion of doctors working with the disabled. Health problems of children with disabilities occur in certain specific situations in their lives. These are special stages of life, which result in individual needs for help. Adolescence and gynecological problems of disabled and dependent women are examples of such periods of life. Specific needs are associated with the dental care of patients with intellectual disabilities, where a cooperation of a dentist with a patient is sometimes impossible. For children with disabilities, dental care sometimes requires non-standard, and very rarely employed measures. As a consequence, it sometimes becomes a source of conflict situations. Despite the fact that mothers often felt resentful about the difficulties, they showed determination and coped with specific situations related to the health of their children.

\section{The future of a child with disability}

The anxiety expressed by the mothers often concerned the situation of their child after graduating from special school. Mothers worried that their children would lose the skills they have acquired, that they would have to spend idle time at home, that there would be no place for their child at WTZ or in other forms of activities. There was also a statement indicating that thanks to the fact that a child goes to school, mother has the opportunity to do some errands, take some break from taking care of her child, or participate in social life.

Wioleta: "Until 14 years old the child can attend school, but what comes next? There are no institutions that would take care of these children. There is one WTZ - but the places are already taken for a few years, a second WTZ would need to be created. I'm worried about what will happen after my child graduates from school".

Beata: "WTZ - each of them would like to (accept) a child who is more fit and independent, but the children with limitations, in a wheelchair - they need assistance even when going to the toilet, for instance. Because I have taught my child that we need to go to the bathroom - but you have to take her by the hand and lead her there, you need to remind her about it. But if you ask her: Iza, do you want to pee? She will say she does not want to, you have to take her to the bathroom. I did not teach her all this so that now they tell me to diaper her, and my child regresses. Her hands are functional, but she needs help because she has some limitations, for example when making a sandwich. I am worried that there will be more candidates to WTZ and they will be more fit than my child. We have this year and the next one, and then it will be harder. If there is no new WTZ, my child will be "closed" at home, and being "closed" at home equals regression. There is Caritas, but they are looking for quite independent children there who are able to take care of themselves. There is also the second department, but the children are all mixed up: some with autism, some with mental disorders. My friend placed her child with autism there, and it was implied to her to take a child - as if they were shoving this child away. At Prosta Street, 
there is another WTZ, but they want independent children. Something is being built at Brzeska Street, but I don't know what is it supposed to be, and on what terms it will be functioning... (...) After graduating from school, some children stay at home. When children are at school, family life looks different, parents have time to run errands, to work, because their child is looked after at school. When the child turns 24 , and he or she is again at home and is still dependent, parents have to take care of the child and be all the time present at home again".

Quite often a mother expresses her anxiety about the child's future after her death. Below is an exemplary statement, although each of the women surveyed perceives it as a serious problem. Not all mothers wanted to comment on this topic.

Beata said: "And the future of the child. What will happen when we are no longer here? I hope my child would go to some good care facility. I would not like to burden my son with this responsibility, because you know... he will have his own family. Even if my son wants it, but who knows how his life will go on - maybe he will have a wife and children in the future. How it all will go... He is still studying but is already working too. He is arranging his life in Warsaw. Do I have the right to disturb his life, to put the burden of taking care of his sister on his shoulders? I do not want it".

Krystyna: "I and my husband often talk about the future of my son, but we haven't talked about it with the children yet. We will leave the apartment for Konrad. I count on the children, I hope that they will get along, that they will be able to decide who should look after Konrad, they love him very much. He will definitely stay in the family".

Mothers point to the importance of WTZ in the rehabilitation of adult children with disabilities, and at the same time they emphasize the fact that there are not enough of the WTZs. The future of their children is becoming a serious problem. Mothers often do not want to burden their other children with taking care of their disabled siblings. However, they often cannot see any other option.

\section{Mothers' dreams...}

By getting to know what the mothers dream about, we have the opportunity to discover specific problems that are difficult to identify, and that the researcher would not ask herself.

Wioleta: "More peace... I like my life, I have learned a lot by having a child, my child is quite independent, he can dress himself, walk, wash himself, eat the prepared meal. However, you have to watch him so that he does not get into mischief, he needs to be occupied all the time (10 minutes of inattention and he was at the oven, began to burn some papers, burned the rug in front of the central heating oven). The state should support mothers whose children with disabilities have died because they were deprived of benefits. Greater help for mothers having children in wheelchairs".

Beata: "Dreams always revolve around the child and his future, we wish we could stop worrying about it, that there is some form of help for the children who are less independent. What will happen if the parents are not around anymore - we wish we could stop worrying about it. I'm worried about what will happen two years after graduating from school, I don't want my daughter to be home, but she may lose her fight for a place at WTZ".

Anna: "To live as long as possible to be able to look after the girls, I don't want to burden my daughter with this responsibility, to have financial resources, enough money for everyday needs and for emergency situations - if they occur. Now I am getting a benefit in the amount of PLN 720, care allowance of PLN 153, and the disability pension of PLN 1,406".

Krystyna: "I wish the health problems end. I would like to live to see the dolphinarium - in Russia - but this is an unrealistic dream. To go to the mountains - this will probably happen".

As it can be expected, the dreams of women often revolved around their children, their health, their future. Quite apparent in them were the need for peace, for sense of security in everyday existence, the need for some rest, trips to dream places.

\section{Discussion}

From the moment a disabled child appears in the family, the roles, functions and family structure change immediately. According to opinion of Popielecki and Zeman, what happens in the family is the disturbance of life plans of the parents and the entire family, and the disturbance of expectations for the newborn child. The emotions are often so strong that relationships between family members and the natural course of everyday life become disorganized [11]. Shock, anxiety, uncertainty are typical feelings of parents, and this fact is confirmed by the author's own research [12]. Many authors pointed to the difficulties in the functioning of a family raising a child with a disability, they were among others: Zalewska (1995) [13], Chodkowska (1995) [14], Otrębski (2011) 
[15], Liberska (2011) [16], Stelter (2013) [17]. The authors distinguished various difficulties that can be classified as emotional, financial, economic, rehabilitation and health related problems, institutional, psychological and social problems.

Limitations in the functioning of the family resulting from the fact of a child's disability pose a real threat of exclusion from social life, and of arising specific social situations that are unusual in families raising a nondisabled child. We know, from "Diagnoza Społeczna" of 2009 and 2011, that social marginalization of disabled people had four basic dimensions, the most important of which concerned the availability of rehabilitation and medical services. The third dimension was the socially established negative perception of people with disabilities $[18,19]$. According to Bartkowski, in three subsequent editions of "Diagnoza Społeczna" it was noticed that the disabled people felt more powerless and humiliated when dealing with official issues [20].

The detrimental consequence of inappropriate social attitudes towards children with disabilities is often pointed out. Dykcik claimed that the possibilities of self-realization of disabled people depend, among other things, on social attitudes, approach and consent, that to a lesser or greater degree provide a sense of security [21]. A similar position was presented by Chodkowska [14]. Adverse consequences of negative social attitudes were pointed out by Pisula. She suggested that this kind of experiences may result in isolation, withdrawal or avoiding social contacts [22].

Konieczna addressed the question of how parents of children with intellectual disabilities approach the issue of ensuring their child a dignified existence in the event of their own illness and/or death. She examined 50 parents of children with intellectual disabilities. Parents were aged 51-60. The respondents were most worried about the future of the child due to the fact that they could not be sure if the child will receive adequate care (65\%). Parents were worried that their children would be lonely and inept (approx. 60\%) and that their child will be in a difficult financial situation (25\%). Over half of the parents thought about their child's future often and very often [23].

\section{Conclusions}

1. In specific phases of the lives of people with disabilities there are special needs of patients with disabilities that require non-standard ways of providing medical assistance.

2. There are mothers who feel called to raise awareness in the society about the issues of proper social attitudes, they show themselves in public, actively work to create more pro-social behavior towards people with disabilities, criticize immature and unethical behavior - these are mothers such as Krystyna. This kind of parents was also described by Kościelska [24].

3. The attitudes of the mothers who participated in the research indicate that women can help each other, are resourceful and active in dealing with issues related to their children.

4. However, the mothers feel helpless about planning the future for their children with disabilities, especially in the situations where schooling ends or what happens to their child when the parents are no longer around.

5. There is a need for macrostructural measures in the form of institutional mechanisms that would allow to include families raising a child with a disability into the general current of social life in the aspect of medical assistance, in relation to the future of children with disabilities. Gąciarz proposes similar theses [25]. An example of such help seems to be the Life Farm (Farma Życia), where are the adults diagnosed with autism. However, there are still not enough of such projects.

6. The point of reference for all activities supporting families with disabled children should be the right to subjective treatment of each person, as Górniewicz writes "the right to be yourself and to be treated as a person" [26]. This is the prism through which the treatment of children with disabilities and their parents should be assessed in institutions, hospitals, laws and regulations regarding the system of supporting them.

At the end, I would like to quote the mother's statement, which indicates the importance of support groups, especially those composed of parents in a similar situation:

Krystyna: "If it so happens that the mother is inept, has a relatively low level of education, and additionally low standards of living, it is reasonable to stimulate her to search for solutions related to expenses, arrangement of housework, and childcare by external support groups and institutions. The support group has a potential to mobilize individual's strength to fight illness or disability, makes it easier to cope with emotions, often negative and incomprehensible to parents. I subscribed to the quarterly magazine "Bardziej Kochani", I wrote a letter to them about my experiences, and later, it was published. The editors sent me letters written by two mothers who have recently given birth to children with Down syndrome, one of the women was only 19 years old. I maintained 
correspondence with these mothers for a long time, I think I helped them to accept their situation. I wrote in a letter:

You have given birth to a healthy child - you are happy.

You have given birth to a disabled child - you are happier".

The research isolated examples of difficulties in the area of social attitudes, contacts with institutions aimed at supporting people with disabilities, difficulties of a medial nature. The interviews do not have the character of representative studies - however, they are extremely valuable due to specific examples of situations and events that these mothers experienced.

\section{References:}

1. Romanowicz W, Bergier J, Tomczyszyn D. [Gender as a factor differentiating conditions of functioning of the disabled in the rural environment of Lublin Region]. Medycyna Ogólna i Nauki o Zdrowiu. 2014; 20(3): 314319 (in Polish). https://doi.org/10.5604/20834543.1124664

2. Budrowska B. [Motherhood as a turning point in a woman's life]. Wrocław: Wyd. Fundacja na rzecz Nauki Polskiej; 2000 (in Polish).

3. Kaczmarek E. [Child's autism as a borderline situation in a father's life. Socio-cultural aspect]. In: Wiśniewska J., editor. [Borderline situations in human life]. Warszawa: Wyd. APS; 2015. p. 93-106 (in Polish).

4. Lindyberg I. [World(s) of the "disabled" motherhood]. Kraków: Oficyna Wydawnicza Impuls; 2012 (in Polish).

5. Dąbrowska M. [Burnout syndrome in mothers of disabled children]. Kraków: Oficyna Wydawnicza Impuls; 2005 (in Polish).

6. Maciarz A. [Motherhood in the context of social changes]. Warszawa: Wydawnictwo Akademickie „Żak”; 2004 (in Polish).

7. Goldenberg H, Goldenberg I. [Family therapy: an overview]. Kraków: Wydawnictwo Uniwersytetu Jagiellońskiego; 2006 (in Polish).

8. Obuchowska I. [Children with lesser opportunities: here and now]. In: Wenta K, Zeindler W., editors. [Pedagogical-psychological diagnosis in the face of transformational risks]. Szczecin: Wyd. Kwadra; 2003. p. 53-60 (in Polish).

9. Larkowa H. [Social attitudes towards the disabled]. In: Hulek A., editor. [Revalidation pedagogy]. Warszawa: Wyd. PWN; 1980. p. 478-491 (in Polish).

10. Sandecka E, Wiśniewska E, Krajewska-Kułak E, Kułak W. [Social functioning of family with disabled child]. Neurologia Dziecięca. 2016; 51(25): 67-73 (in Polish).

11. Popielecki M, Zeman I. [Psychological crisis caused by the birth of a disabled child]. Szkoła Specjalna. 2000; 1: 15-19 (in Polish).

12. Tomczyszyn D. [The role of the mother and father in the family of an intellectually disabled child]. Biała Podlaska: Wyd. PSW; 2015 (in Polish).

13. Zalewska M. [Psychological aspects of the diagnosis of deafness in a child]. In: Pisula E, Rola J., editors. [Chosen problems of the psychological diagnosis of developmental disorders in children]. Warszawa: Wyd. WSPS; 1995. p. 90-97 (in Polish).

14. Chodkowska M. [Disabled child in the family. Socialization and rehabilitation]. Lublin: Wyd. UMCS; 1995 (in Polish).

15. Otrębski W, Konefał K, Mariańczyk K, Kulik MM. [Supporting families with disabled children as a challenge for social work. Study of families with disabled children in Lublin Voivodeship]. Lublin: Wyd. Europerspektywa; 2011 (in Polish).

16. Liberska H. [Introduction]. In: Liberska H., editor. [Family of a disabled child - opportunities and constraints for the development]. Warszawa: Wyd. Difin; 2011. p. 4-5 (in Polish).

17. Stelter Ż. [Performing parental roles to an intellectually disabled child]. Warszawa: Wyd. Difin; 2013 (in Polish).

18. Czapiński J, Panek T. [Disability]. In: Czapiński J, Panek T., editors. [Social diagnosis 2009. Conditions and quality of life in Poland] [Internet]. Warszawa: Rada Monitoringu Społecznego; 2009 [cited 2019 Sep 16]; p. 333-336. Available from: http://www.diagnoza.com/pliki/raporty/Diagnoza_raport_2009.pdf (in Polish).

19. Czapiński J, Panek T. [Social diagnosis 2011. Conditions and quality of life in Poland] [Internet]. Warszawa: Rada Monitoringu Społecznego; 2011 [cited 2019 Sep 16]; p. 328-352.

Available from: http://www.diagnoza.com/pliki/raporty/Diagnoza_raport_2011.pdf (in Polish).

20. Bartkowski J. [Socio-economic situation and quality of life of the disabled in Poland]. In: Gąciarz B, Rudnicki S., editors. [Polish disabled: from comprehensive diagnosis to a new model of social policy]. Kraków: Wyd. AGH; 2014. p.45-104 (in Polish). 
21. Dykcik W. [Special needs pedagogy]. Poznań: Wydawnictwo Naukowe UAM; 2001 (in Polish).

22. Pisula E. [Parents and siblings of children with developmental disorders]. Warszawa: Wyd. UW; 2007 (in Polish).

23. Konieczna A. [Parents' aspirations for their disabled children's professional activity - fear for the future]. In: Tomczyszyn D, Romanowicz W., editors. [Professional activity of the disabled]. Biała Podlaska: Wyd. PSW; 2012. p. 277-282 (in Polish).

24. Kościelska M. [Aspects of disability]. Warszawa: Wyd. Naukowe PAN; 1995 (in Polish).

25. Gąciarz B. [Rethinking disability. From welfare state institutions to integration and social activisation]. Studia Socjologiczne. 2014; 213(2): 15-42 (in Polish).

26. Górniewicz J. [Pedagogical categories]. Olsztyn: Wyd. OSW; 2001 (in Polish). 